\title{
Studie prínosu extenzivní stabilizace čistírenských kalů z malých komunálních zdrojů pro jejich využití jako hnojiva
}

\section{JOSEF KRATINA, MILOŠ ROZKOŠNÝ, HANA HUDCOVÁ, MICHAL ŠEREŠ, ONDŘEJ HOLUBíK}

Klíčová slova: čistírenský kal - odvodnění kalu - stabilizace kalu - kvalita půdy - organická hmota - kompostování - hnojivo

\section{SOUHRN}

Článek je věnován prezentaci dílčích výsledků studie zaměřené na stanovení potenciálu využití extenzivní technologie odvodnění kalu pro malé komunální Čistírny odpadních vod (ČOV, do 1000 EO) v podmínkách ČR. Studie prokázala, že využití technologie založené na extenzivním odvodnění kalů a jejich stabilizaci v kalových polích s vhodnou mokřadní vegetací může představovat alternativu k jiným technologiím, zejména v kombinaci s kořenovými ČOV které se vyznačují menší produkcí kalu. Podmínkou je dostatečně velká plocha pozemků, což je často príiklad malých obcí, jež kořenové ČOV využívají. Popsaná technologie odvodnění čistírenských kalů může být prvním stupněm zpracování, které príi zajištění následné vhodné úpravy a standardizace substrátů (přídavkem dalších príměsí, následným zpracováním do peletek apod.) otevírá cestu pro racionální využití kalů pro zvýšení kvality orné půdy. Předpokládáme, že aplikace organominerálních hnojiv do pưdy bude mít vysoce pozitivní vliv nejen pro tvorbu stabilní půdní struktury, ale především téměř eliminuje riziko spojené s vyplavováním dusíku (N) a fosforu (P) do vod.

\section{ÚVOD}

V současné době celosvětově narůstá problém s likvidací odpadů. Jejich druhotné využití je proto víc než žádoucí. Palčivým problémem malých obcí, které potřebují vybudovat nebo rekonstruovat ČOV, je uplatnění upraveného kalu na obecní, popř. zemědělské půdě. Není výjimkou, že malým komunálním ČOV chybí tzv. kalová koncovka. Čistírenský kal je tak často s vysokými náklady odčerpáván a převážen do velké ČOV. Obecně přitom platí, že vhodný zemědělský podnik, pro který by upravený a stabilizovaný kal z ČOV mohl být hodnotným zdrojem organických látek a živin, tak nemá možnost tento materiál využít. $\checkmark$ praxi se tudíz stále nedaří zhodnotit materiálové zdroje př́mo v místě jejich vzniku a z dlouhodobého hlediska takto prosazovat základní principy nízkouhlíkové ekonomiky. Hlavním cílem pro reálné uplatnění kalů z ČOV je v budoucnu zabránit poškození půd, rostlin, zdraví zvirǐat i lidí. Z tohoto důvodu, s ohledem na látky př́tomné nyní v kalech (např. organické mikropolutanty), je vhodné kaly dostatečně předupravit, nejen hygienizovat z důvodu eliminace nadlimitního mikrobiálního znečištění.

Správné využití kalů je pro půdu velmi podstatné, nebot upravený kal je bohatým zdrojem organické hmoty, základních živin (dusík, fosfor, draslík, vápník aj.) i stopových prvků. Při správné aplikaci kalu do půdy mưže významně přispět ke zlepšení fyzikálně-chemických i biologických vlastností půdy [1]. Při vhodném poměru $\mathrm{C} / \mathrm{N}$ dochází $v$ půdě $\mathrm{k}$ biotransformaci primárních zdrojů organické hmoty na humus [2]. Formování humózních částic vede k vytvoření stabilní půdní struktury a k posílení retenčních a infiltračních schopností půdy, dále ke snižení rizika eroze a vylepšení vláhové bilance na pozemku apod. [3].

Cílem studie, jejíž výsledky přináší tento článek, bylo posoudit možnost zjednodušení postupů úpravy a stabilizace čistírenských kalů z malých komunálních zdrojů znečištění (ČOV do 1000 EO) v místě jejich vzniku a jejich následné využití. Toto zjednodušení je založeno na využití extenzivního způsobu odvodnění a stabilizace kalů, a to se zohledněním ekonomické efektivnosti. Systém je navržen pro potřeby malých obcí, které nemají v místě čištění odpadních vod realizované kalové hospodářství, a musejí tak jinými způsoby řešit nakládání s čistírenskými kaly a organickým materiálem vzniklým při čištění odpadních vod. Jde o technologii tzv. rákosových kalových polí, nazývanou také reed bed (RB) technologie či reed bed jednotky $[4,5]$.

$\checkmark$ rámci studie byla tato technologie testována $\vee$ poloprovozu jak pro mechanicko-biologické (aktivační) ČOV do 1000 EO (dále jako MBČOV), tak pro tzv. kořenovou ČOV (KČOV) stejné velikostní kategorie. V článku je detailně rozebrána varianta s KČOV, jež je v podstatě také založena na extenzivních čistících procesech, které probíhají ve vodním a mokřadním prostředí. Při prokázání dostatečné účinnosti by bylo možné uvažovat o využití této energeticky méně náročné kombinace ČOV + úprava kalů pro vhodná malá sídla.

\section{METODIKA}

Technologie RB jednotek je určena k pasivnímu odvodňování čistírenských kalů, a to prrímo v místě jejich vzniku. Principem technologie je postupné dávkování surového čistírenského kalu pocházejícího z aktivačních nádrží mechanicko-biologických ČOV, prípadně z objektů mechanického předčištění vod (lapáky písku, septiky, usazovací nádrže rưzných typů) nebo kořenových ČoV, a jeho pozvolné odvodňování na základě filtrace skrze drenážní vrstvu a evapotranspirací s pomocí vysázených mokřadních rostlin. Kal je dávkován v určitých periodách, přičemž v období mezi dávkováním dochází jak ke snížení vlhkosti kalu, tak k jeho pozvolné mineralizaci. Po naplnění kalového pole na provozní maximum je systém odstaven a nastává fáze mineralizace matrice a snížení objemu kalu, aby mohl být opětovně dávkován „čerstvý“ kal. Takto se postupně dosáhne maximální provozní kapacity kalového pole, které je nutno odstavit. Konečnou fází je stabilizace a do určité míry i hygienizace směsi kalu a rozložitelné biomasy mokřadních rostlin, po jejímž ukončení je možné směs odtěžit k využití. Časová náročnost celého cyklu plnění je několik let, dle zkušeností [4] 
nejvýše však deset, v závislosti na projektovaném objemu. Takto upravená kalová pole jsou využívána prakticky celosvětově [6-8]. Celkový přehled k této technologii publikovali autoři studie věnované shrnutí konstrukčních zásad, návrhových parametrů a zjištění o účinnosti odvodnění kalů a jejich stabilizaci [9].

Vlastní studii předcházel dvouletý monitoring složení kalů (2017 a 2018), který probíhal na dvou pilotních lokalitách, a to na KČOV pro malou obec v okrese Vyškov (cca 900 obyvatel) a MBČOV v malé obci v okrese Břeclav (cca 1000 obyvatel). Obě lokality byly využívány i pro experimenty spojené s kompostováním, úpravami vlastností kalů a odvodněním kalů RB jednotkami. Rozdíl mezi Čistírnami nepředstavuje jen technologie čištění, ale i kanalizační sít. KČOV je napojena na jednotnou kanalizační sít obce, MBČOV na oddílnou splaškovou kanalizaci. To se odráží i ve složení odpadních vod a kalů.

Vzorky kalů a odvodněných kalových směsí byly odebírány časově jako bodové, ale prostorově směsné. Pokud jde o MBČOV, zdrojem byla kalová sekce, konkrétně sběrná mobilní vana pro uložení odvodněného kalu, v prípadě KČOV pak sekce mechanického předčištění (vyhnívací prostor štěrbinové usazovací nádrže). Každý vzorek byl umístěn do samostatné vzorkovnice z HDPE a $\vee$ chladnu přepraven do laboratoře. $V$ laboratoři byly vzorky homogenizovány, lyofilizovány a dále zpracovány k analýzám - stanovení sušiny, ztráty žíháním, nutrientů, rizikových prvků či ukazatelư mikrobiálního znečištění (fekální koliformní bakterie, E. coli, salmonely a enterokoky). Analýzy byly prováděny podle běžných akreditovaných postupů vycházejících z řady príslušných ČSN. Obdobně byly odebrány, uchovány a zpracovány vzorky pro stanovení organických mikropolutantů, a to v externí laboratoři metodou LC-MS/MS.

\section{VÝSLEDKY A DISKUZE}

Počáteční fází studie byl dvouletý průzkum složení kalů a jejich kontaminace, který byl proveden na dvou ČOV malých obcí do 2000 EO. Vybrány byly ČOV zastupující obě hlavní technologické skupiny, a to mechanicko-biologické (aktivační) a kořenové ČOV.

Výsledky monitoringu v letech 2017 a 2018 byly zohledněny v další fázi studie, kdy byla navržena extenzivní odvodňovací zařízení na platformě RB jednotek, v poloprovozním měřítku. Pro koncept objemu, zatížení kalem a způsobu provozu (interval napouštění, napouštěné dávky, fáze odvodnění a mineralizace, konečná fáze zrání a stabilizace kalů) byly využity údaje o změnách sušiny v kalu, obsahu organického podílu a mikrobiální kontaminace. Analýza prítomnosti rizikových prvků byla nezbytná pro posouzení rizikovosti a toxicity kalů vzhledem k jejich možnému dalšímu uplatnění jako součásti hnojivých směsí. Naopak analýza množství živin byla důležitá pro vyhodnocení vhodných doplňkových príměsí hnojivých směsí za účelem jejich standardizace, co se obsahu přistupných živin týče. Na obr. 1 a 2 jsou znázorněny obsahy vybraných hygienicky významných bakterií a rizikových prvků v kalech obou pilotních čistíren. Koncentrace enterokoků v kalech obou čistíren měla značný rozptyl, v prípadě KČOV opět v závislosti na stáří kalu. Fekální koliformní bakterie naopak vykazovaly vyšší rozptyl u MBČOV.

$\mathrm{U}$ většiny rizikových prvků (zde vybrány čtyři - $\mathrm{Cd}, \mathrm{Cr}, \mathrm{Hg}$ a Ni) byly zjištěny vyšší obsahy v kalech kořenové čistírny (obr. 3 až 6). Vysvětlujeme si to i vlivem napojení srážkových vod, smyvů ze zpevněných povrchů, smyvů prachu z atmosférických depozic apod. do jednotné kanalizační sítě. Nicméně ani tyto kaly nejsou zatíženy sledovanými prvky nad limit vyhlášky [10] o použití kalů v zemědělství, platné $v$ čase provedení studie. V současnosti stanovuje prakticky stejné limity vyhláška č. 273/2021 Sb., o podrobnostech nakládání s odpady, platná od července 2021.

Na obr. 7 až 11 jsou znázorněny podíly sušiny, obsahy organické složky a vybraných nutrientů. Sušina odebraných vzorků kalů odpovídala stavu jejich zpracování. V prípadě aktivační ČOV byl kal odvodněn odstředivkou (sušina okolo $20 \%$ ). Výkyvy v sušině byly způsobeny poruchami v technologii během

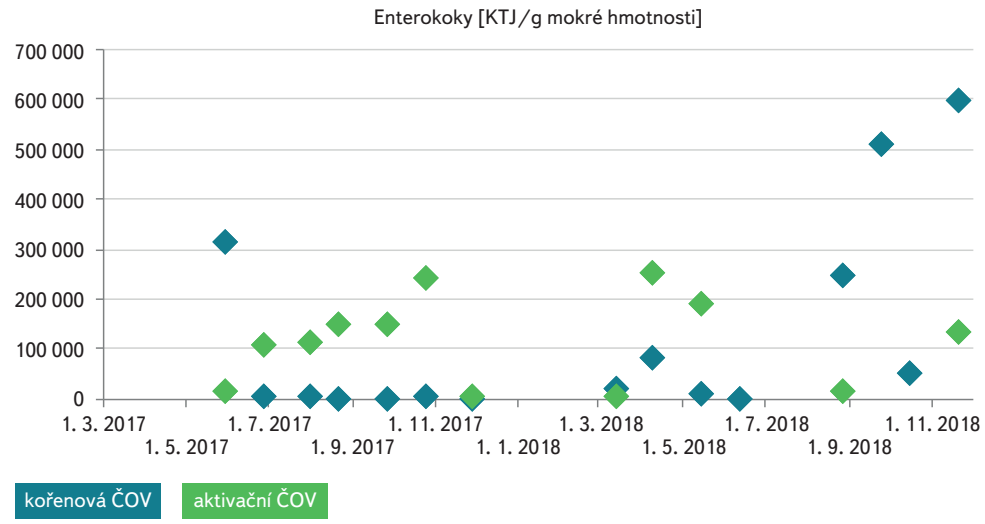

Obr. 1. Obsah enterokoků v kalech

Fig. 1. Enterococci content in the sludges

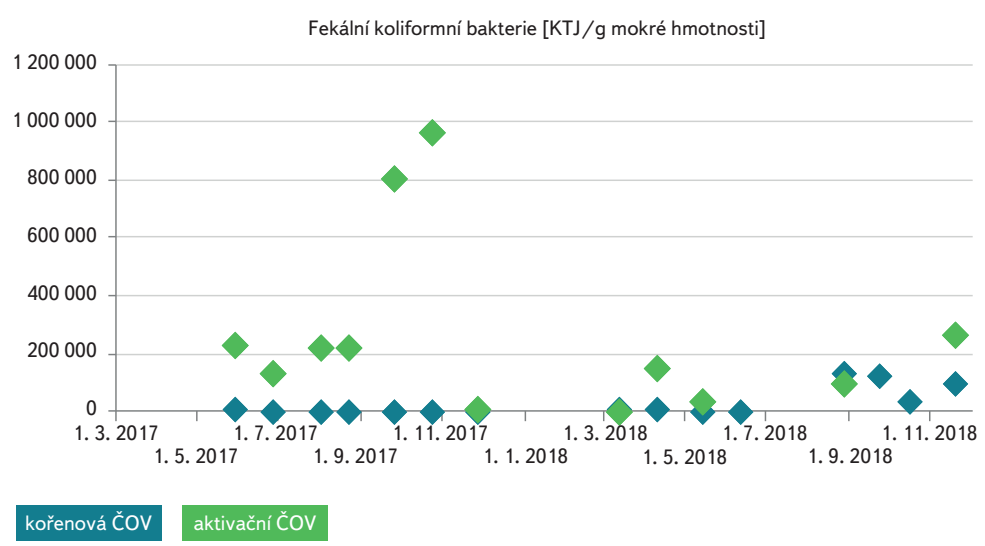

Obr. 2. Obsah fekálních koliformních bakterií v kalech Fig. 2. Faecal coliform bacteria content in the sludges

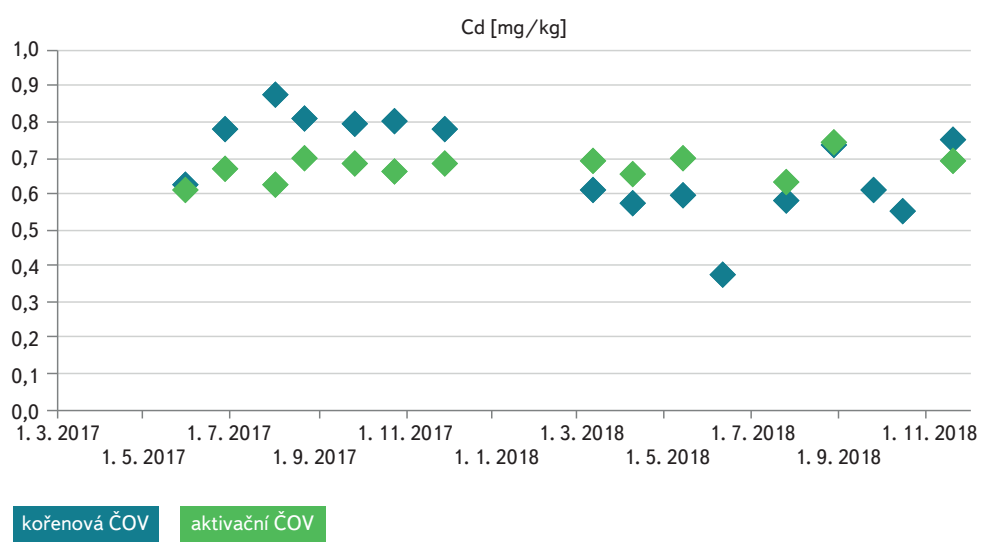

Obr. 3. Obsah kadmia v kalech

Fig. 3. Cadmium content in the sludges

sledovaného období. Sušina kalu kořenové ČOV závisela na stáří kalu. U této ČOV je kal vyvážen z anaerobního vyhnívacího prostoru štěrbinové usazovací nádrže, jakož i z usazovacího prostoru této nádrže a z lapáku písku cca 1× za 3 měsíce. Sušina tak kolísala od rídké směsi pod $10 \%$ až po hodnoty okolo 25 až 30 \%. Vyšší hodnoty souvisí s délkou uložení kalu ve vyhnívacím prostoru. S přibývajícím časem od vyvážení obvykle dochází v horní části vyhnívacího prostoru k tvorbě silné, poměrně suché krusty. Ztráta žíháním a obsah organických látek byly po celou dobu nižší u kalu kořenové čistírny v důsledku jeho anaerobního vyhnívání. 


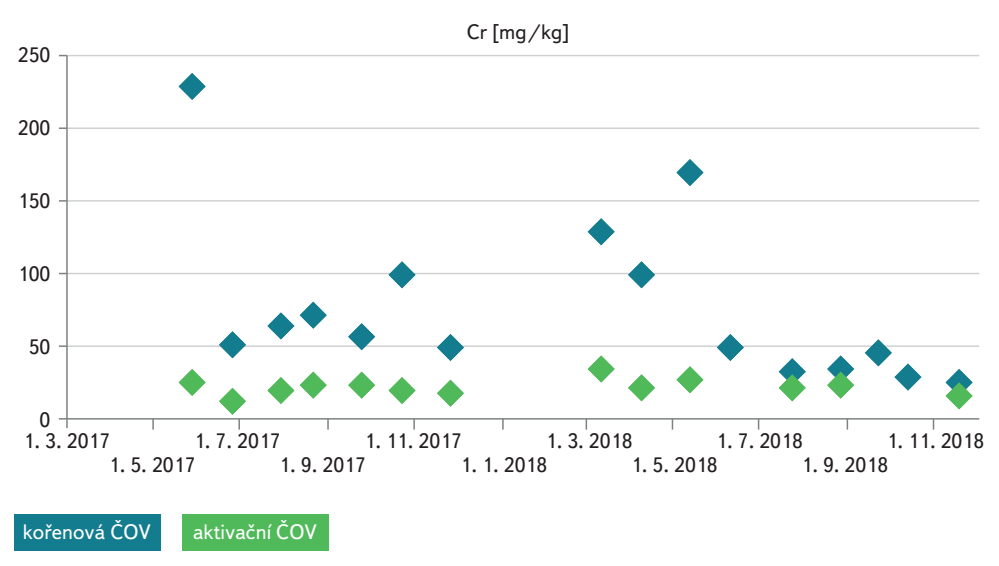

Obr. 4. Obsah chromu v kalech

Fig. 4. Chromium content in the sludges

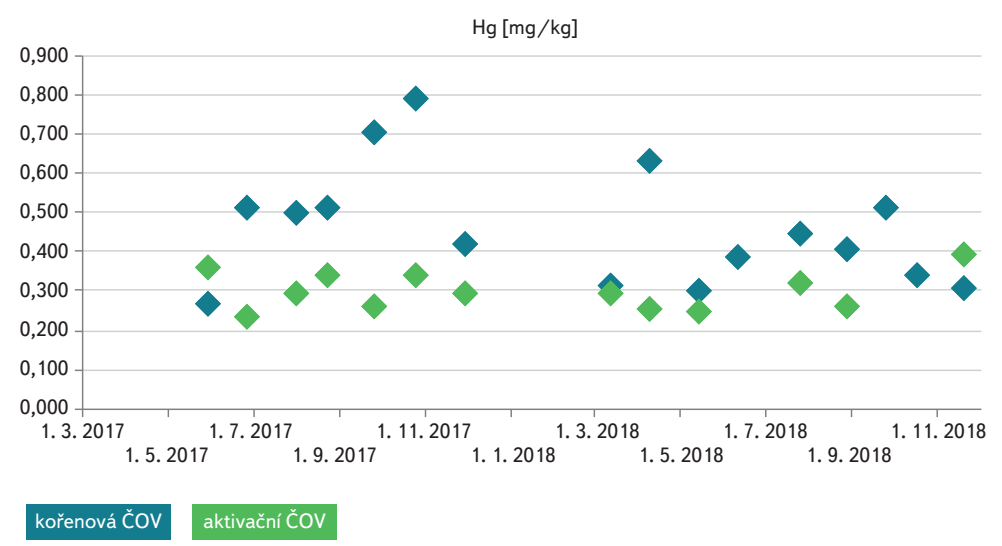

Obr. 5. Obsah rtuti v kalech

Fig. 5. Mercury content in the sludges

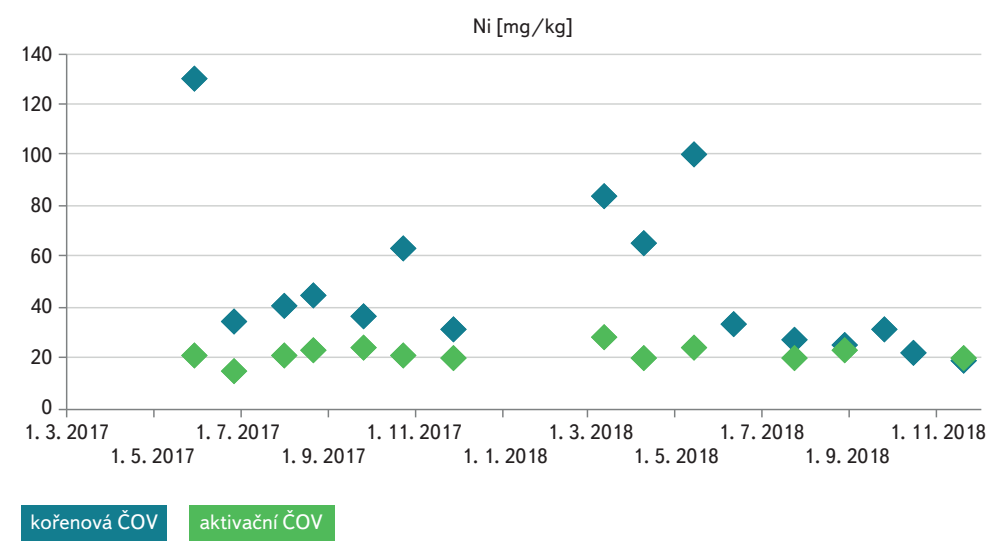

Obr. 6. Obsah niklu v kalech

Fig. 6. Nickel content in the sludges

Obsah fosforu v kalu byl cca $5 \times$ vyšší v prípadě MBČOV. U této čistírny jeho obsah v kalu také značně kolísal. Naopak v kalu kořenové ČOV byl obsah fosforu po celou dobu sledování poměrně stabilní - okolo 5000 mg/kg sušiny kalu. Obsah draslíku byl též výrazně vyšší v kalu MBČOV, a to s velkým rozptylem. Naopak v kalu KČOV byl jeho obsah poměrně stabilní - okolo 2000 mg/kg sušiny kalu. Obtížně vysvětlitelný byl pozorovaný nárůst obsahu vápníku v kalu KČOV. Patrně opět souvisel s aktuálními vlastnostmi a stárím kalu, protože koreluje spíše s nižšími hodnotami sušiny kalu v závěru roku 2018.

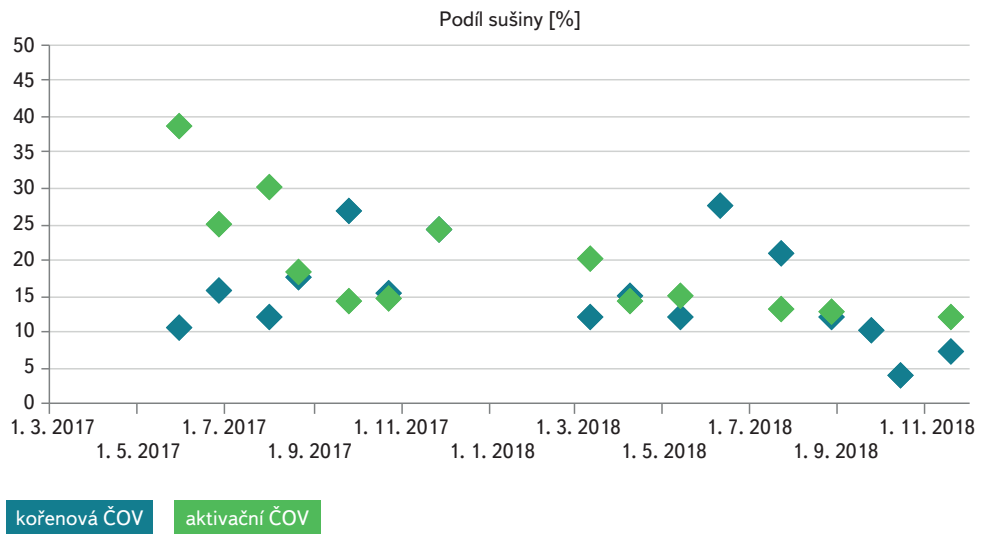

Obr. 7. Podíl sušiny v kalech

Fig. 7. Dry matter ratio of the sludges

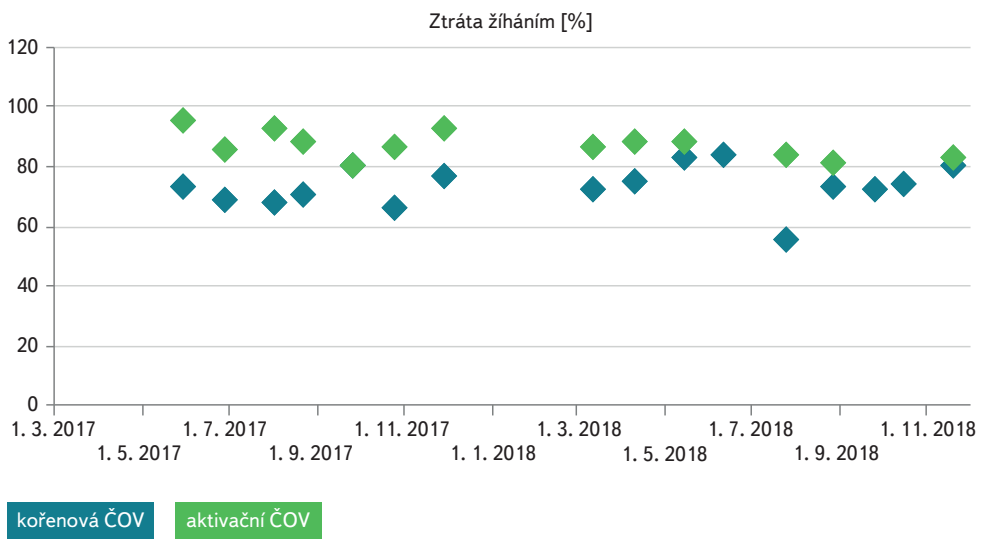

Obr. 8. Ztráta žíháním v kalech

Fig. 8. Organic matter content in the sludges

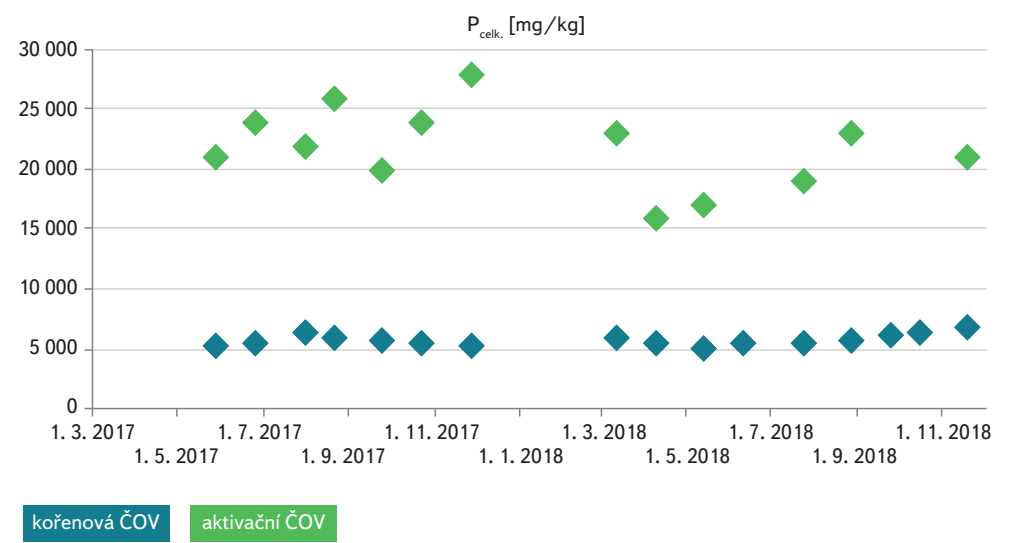

Obr. 9. Obsah fosforu v kalech

Fig. 9. Phosphorus content in the sludges

S ohledem na výsledky dvouletého monitoringu, který odhalil pro některé ukazatele podstatný rozdíl mezi kalem vybraných typů ČOV, a s ohledem na produkci kalu těmito ČOV, kdy KČOV se vyznačovala významně menší produkcí, bylo rozhodnuto, že v rámci studie má větší perspektivu propojení RB jednotky k odvodnění a stabilizaci kalu s KČOV. I když byly i nadále prováděny poloprovozní experimenty s využitím RB jednotek pro MBČOV, pozornost byla soustředěna na kombinaci KČOV + poloprovozní RB jednotky v kombinaci se zakrytím a bez zakrytí skleníkem [5]. Dále v článku jsou tedy detailně rozvedeny výsledky 


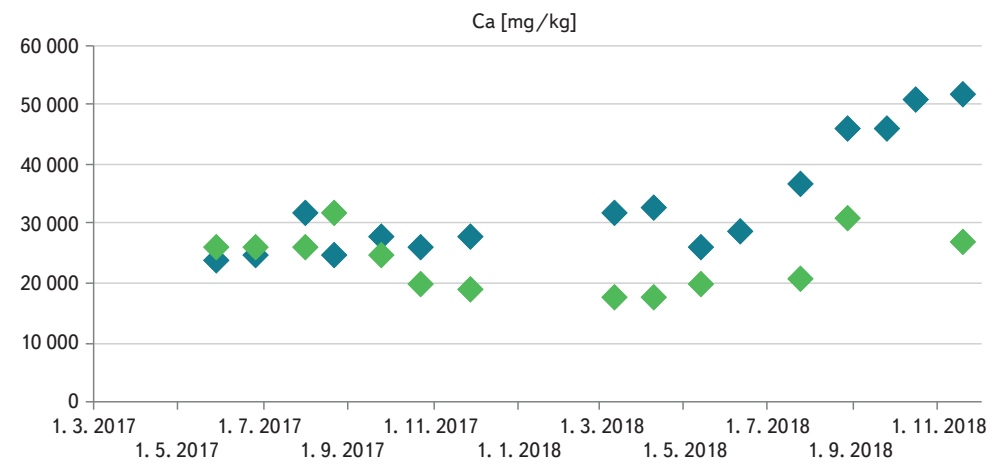

kořenová Čov

Obr. 10. Obsah vápníku v kalech

Fig. 10. Calcium content in the sludges

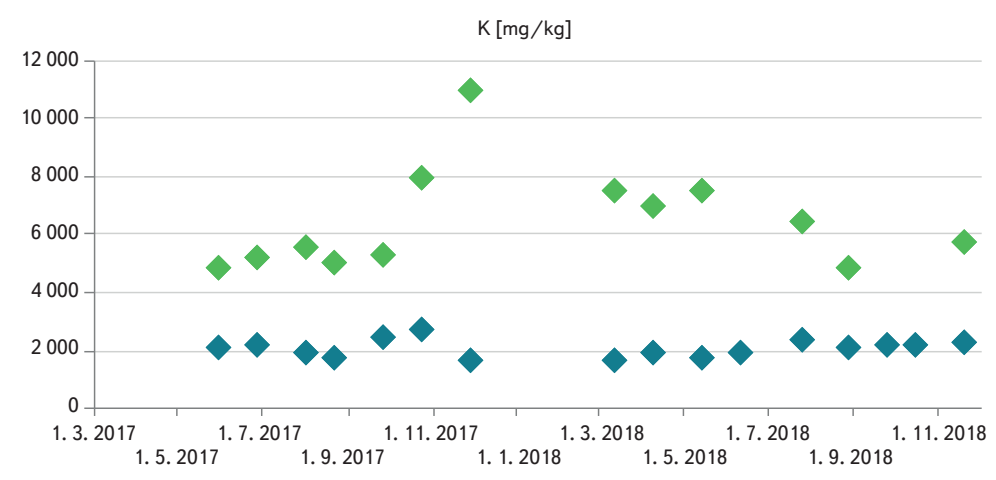

kořenová ČOV

Obr. 11. Obsah draslíku v kalech

Fig. 11. Potassium content in the sludges

této kombinace. Použití RB jednotky k odvodnění a stabilizaci kalu MBČOV vyžaduje zcela odlišný režim provozu a napouštění, které povedou k obdobné míre stabilizace kalu [5].

Tab. 1 zobrazuje změny obsahu rizikových prvků - převážně kovů, mikrobiální kontaminace a obsahu vybraných nutrientů, stejně jako sušiny a ztráty žíháním (obsahu organického podílu) během procesů nakládání se vstupním surovým kalem KČOV. A to přes odvodnění a hygienizaci pozvolným samostatně běžícím procesem biologické stabilizace během uložení v RB jednotce, navazující sítování výsledné směsi z RB jednotky preses síto 4 mm až po finální produkty - hnojivé směsi.

Patrný je zásadní úbytek mikrobiální kontaminace během procesu odvodnění a stabilizace. Mikrobiální kontaminace zcela vymizí díky tepelné úpravě při prípravě hnojivých směsí. Současně dochází ke zhruba polovičnímu úbytku organického podílu (pokles ztráty žíháním). Jak na vstupu, tak i v konečných produktech nebyly zjištěny nadlimitní koncentrace sledovaných těžkých kovů a rizikových prvků, i když odvodněním a stabilizací v RB jednotce dochází k určitému stupni zakoncentrování.

Jak bylo uvedeno výše, hodnocení obsahu rizikových prvků a mikrobiální kontaminace kalů a materiálů bylo v čase provádění studie zpracováno s využitím vyhlášky č. 437/2016 Sb. [10], která však byla s novelizací legislativy k nakládání s odpady zrušena, a to $k$ 1. lednu 2021. Náhradou by měla být vyhláška č. 273/2021 Sb., o podrobnostech nakládání s odpady. Ta definuje prakticky totožné limitní hodnoty. Všechny výše zmíněné materiály splňovaly stanovené požadavky na obsah rizikových látek.
Uvedené údaje o zjištěných koncentracích rizikových prvků a mikrobiálním znečištění lze porovnat s výsledky rozsáhlejšího průzkumu malých ČOV různých technologií [11]. Výsledky pro vstupní kalovou směs jsou srovnatelné. Zjištěné koncentrace v odvodněné směsi odpovídaji údajům publikovaným v zahraničí, např. v rámci studie Uggetti a kol. [9].

Součástí studie bylo také provedení analýz na obsah rizikových látek ze skupiny organických mikropolutantů, zejména léčiv. Tab. 2 a 3 prezentují výsledky jednorázově provedených analýz jak ve vzorcích vstupních kalových směsí, tak ve výsledných odvodněných směsích kalu a vegetace rákosu obecného nacházejících se během provozu na povrchu RB jednotek za sezonu 2018 a 2019. Jde o lokalitu KČOV.

Ve dvou směsných vzorcích, reprezentujících vstupní kal a výslednou odvodněnou a stabilizovanou směs kalu a biomasy ze sezony 2018, bylo analyzováno 44 vybraných organických mikropolutantů. Z toho 22 nebylo prokázáno ani ve vstupním kalu (50 \% látek). U 10 látek došlo k významné eliminaci, protože nebyly zvolenou analytickou metodou ve výstupní směsi detekovány. U sedmi dalších látek byl zjištěn úbytek nad $75 \%$, u dvou látek úbytek nad $70 \%$ a u jedné nad $50 \%$. Úbytek definujeme jako rozdíl mezi změřenou vstupní (ve vstupním kalu) a výstupní (kalová směs po skončení procesu odvodnění a stabilizace) koncentrací. U triclocarbanu byla naměěena vyšší koncentrace ve výstupní směsi. Tato látka bývá, spolu s triclosanem (látka s úbytkem cca 51 \%), př́tomna v mýdlech, zubních pastách, deodorantech apod.

Ve vzorcích za sezonu 2019 již bylo analyzováno 67 látek. Z toho 44 nebylo prokázáno ani ve vstupním kalu (66 \% látek). U 13 látek došlo k významné eliminaci, protože nebyly zvolenou analytickou metodou ve výstupní směsi detekovány. U šesti dalších látek byl zjištěn úbytek nad $75 \%$, u dvou nad $50 \%$. U triclocarbanu (antimikrobiální a antifungální sloučenina) byla opět zjištěna vyšší koncentrace ve výstupní směsi. Z nově analyzovaných látek byla naměřena vyšší koncentrace ve výstupní směsi u látky celiprotol (základ léku pro léčbu vysokého krevního tlaku). Nepatrný rozdíl v koncentraci byl u látky irbesartan (základ léku pro léčbu vysokého tlaku a diabetických chorob ledvin).

Analýza změn obsahu sušiny a organického podílu během provozu RB jednotek $v$ návaznosti na napouštění surové kalové směsi uskutečněná $v$ rámci výzkumné studie je podrobně popsána v článku [5]. RB jednotky byly plněny tekutým kalem se sušinou mezi 2 až $13 \%$, v závislosti na původu kalu a s použitím různých schémat nakládání pro studované období 2017-2019. RB jednotky prokázaly velmi slibné výsledky, pokud jde o odvodnění kalu. Na konci každé kampaně odvodnění bylo dosahováno 30-40 \% sušiny kalu. V př́padě jednotky RB zakryté skleníkem dosáhlo odvodňování kalu hodnot sušiny mezi 51 \% a 80 \% v závislosti na ročním období a klimatických podmínkách. Vliv vstupních charakteristik kalů a posouzení vlivu volby př́tokového zatížení se věnuje článek Vincenta a kol. [12]. Návrhové zatížení a způsob provozu námi využitých poloprovozních RB jednotek [5] odpovídá doporučením výše zmíněné publikace.

Jak již bylo uvedeno v úvodu, s ohledem na prítomnost řady běžně nesledovaných polutantů v čistírenských kalech, viz např. uvedené organické mikropolutanty, praxe směřuje k využívání návazných technologií zpracování kalů před jejich možným následným využitím. Dalším krokem vedoucím k uplatnění upravených a stabilizovaných čistírenských kalů v zemědělství je tedy volba vhodné technologie dosoušení kalu a prípravy organominerálních hnojiv. Jak obstojí na trhu, bude záviset především na ověření kvality a ceny těchto materiálů oproti standardním dávkám hnojiv typu NPK. Za tímto účelem je vhodné standardizovat obsah potřebných živin $v$ dostupné formě pro vegetaci, a to např. přidáním dalších složek během zpracování na konečný produkt.

$\checkmark$ rámci naší studie padla volba na zpracování odvodněných a stabilizovaných směsí kompostováním a peletkováním. V článku je dále prezentována část věnovaná peletkování. Cílem bylo připravit a odzkoušet dvě různé varianty hnojiva ve formě organominerální peletky: 
Tab. 1. Porovnání složeni a kontaminace vstupního kalu, finálních materiálù z RB jednotek a hnojivých produktů

Tab. 1. Comparison of composition and contamination of input sludge, final materials from RB units and fertilizer products

\begin{tabular}{|c|c|c|c|c|c|c|}
\hline Označení materiálu & $\begin{array}{l}\text { Enterokoky } \\
\text { [KTJ/g sušiny] }\end{array}$ & $\begin{array}{l}\text { Escherichia coli } \\
\text { [KTJ/g sušiny] }\end{array}$ & $\begin{array}{l}\text { Fek. kolif. bakt. } \\
\text { [KTJ/g sušiny] }\end{array}$ & Salmonely & $\begin{array}{l}\text { Kultiv. MO při } \\
22^{\circ} \mathrm{C} \\
{[\mathrm{KTJ} / \mathrm{g} \text { sušiny] }}\end{array}$ & $\begin{array}{l}\text { Kultiv. MO } \\
\text { při } 36{ }^{\circ} \mathrm{C} \\
{[\mathrm{KTJ} / \mathrm{g} \text { sušiny] }}\end{array}$ \\
\hline Vstupní kalová směs & 6880000 & 1870000 & 2530000 & $\begin{array}{l}\text { neg. } \vee 50 \mathrm{~g} \\
\text { materiálu }\end{array}$ & 1990000000 & 486000000 \\
\hline Finální materiál z RB jednotky & 2060 & 8260 & 26800 & & 80500000 & 78400000 \\
\hline $\begin{array}{l}\text { Finální materiál z RB jednotky } \\
\text { sítovaný [síto } 4 \text { mm] }\end{array}$ & 162 & 162 & 324 & & 140000000 & 76200000 \\
\hline Hnojivo "Startér S1" & 0 & 0 & 0 & & 1240000 & 688000 \\
\hline Hnojivo „Fertilizér F1" & 0 & 0 & 0 & & 12000000 & 8940000 \\
\hline Limitní hodnoty [10] & $5 \mathrm{vz} .<1000$ & & 5 vz. $<1000$ & $\begin{array}{l}\text { neg. v } 50 \text { g } \\
\text { materiálu }\end{array}$ & & \\
\hline
\end{tabular}

\begin{tabular}{|c|c|c|c|c|c|c|c|c|c|}
\hline Označení materiálu & $\begin{array}{l}\text { VL ztráta } \\
\text { žíháním [\%] }\end{array}$ & $\begin{array}{l}\text { Sušina } \\
\text { [\%] }\end{array}$ & $\begin{array}{l}\text { P celk. } \\
{[\mathrm{mg} / \mathrm{kg}]}\end{array}$ & $\begin{array}{l}\mathrm{Na} \\
{[\mathrm{mg} / \mathrm{kg}]}\end{array}$ & $\begin{array}{l}\mathrm{K} \\
{[\mathrm{mg} / \mathrm{kg}]}\end{array}$ & $\begin{array}{l}\mathrm{Ca} \\
{[\mathrm{mg} / \mathrm{kg}]}\end{array}$ & $\begin{array}{l}\mathrm{Mg} \\
{[\mathrm{mg} / \mathrm{kg}]}\end{array}$ & $\begin{array}{l}\mathrm{Fe} \\
{[\mathrm{mg} / \mathrm{kg}]}\end{array}$ & $\begin{array}{l}\mathrm{Mn} \\
{[\mathrm{mg} / \mathrm{kg}]}\end{array}$ \\
\hline Vstupní kalová směs & 60,2 & 8,7 & 5600 & 640 & 1800 & 22000 & 2800 & 6900 & 110 \\
\hline $\begin{array}{l}\text { Finální materiál } \\
\text { z RB jednotky }\end{array}$ & 30,4 & 48,5 & 11000 & 520 & 2800 & 56000 & 5900 & 19000 & 320 \\
\hline $\begin{array}{l}\text { Finální materiál } \\
\text { z RB jednotky } \\
\text { sítovaný [síto } 4 \text { mm] }\end{array}$ & 28,8 & 57,5 & 11000 & 610 & 4300 & 52000 & 6200 & 20000 & 340 \\
\hline Hnojivo "Startér S1" & 39,4 & 88,2 & 33000 & 470 & 34000 & 35000 & 11000 & 15000 & 240 \\
\hline Hnojivo „Fertilizér F1“ & 29,8 & 87,3 & 13000 & 610 & 4100 & 70000 & 6600 & 27000 & 360 \\
\hline Limitní hodnoty [10] & - & - & - & - & - & - & - & - & - \\
\hline
\end{tabular}

\begin{tabular}{|c|c|c|c|c|c|c|c|c|c|c|c|c|c|}
\hline \multirow{2}{*}{ Označení materiálu } & Al & As & $\mathrm{Be}$ & Cd & Co & $\mathrm{Cr}$ & $\mathrm{Cu}$ & $\mathrm{Hg}$ & Mo & $\mathrm{Ni}$ & $\mathbf{P b}$ & $\mathbf{V}$ & Zn \\
\hline & \multicolumn{13}{|c|}{$[\mathrm{mg} / \mathrm{kg}]$} \\
\hline Vstupní kalová směs & 6000 & $<4,5$ & 0,27 & 0,50 & 7,6 & 20 & 99 & 0,28 & 1,8 & 15 & 12 & 14 & 550 \\
\hline Finální materiál z RB jednotky & 14000 & 6,0 & 0,68 & 0,97 & 6,7 & 39 & 220 & 0,75 & 3,1 & 32 & 36 & 32 & 1100 \\
\hline $\begin{array}{l}\text { Finální materiál z RB jednotky } \\
\text { sítovaný (síto } 4 \text { mm) }\end{array}$ & 19000 & 6,5 & 0,82 & 0,94 & 7,3 & 47 & 210 & 0,78 & 3,1 & 30 & 39 & 40 & 1100 \\
\hline Hnojivo "Startér S1" & 12000 & 4,4 & 0,56 & 0,73 & 49 & 36 & 170 & 0,58 & 26 & 22 & 36 & 26 & 800 \\
\hline Hnojivo "Fertilizér F1" & 18000 & 7,3 & 0,78 & 0,96 & 7,4 & 48 & 210 & 0,55 & 3,8 & 29 & 44 & 40 & 1000 \\
\hline Limitní hodnoty [10] & - & 30 & - & 5 & - & 200 & 500 & 4 & - & 100 & 200 & - & 2500 \\
\hline
\end{tabular}


Tab. 2. Výsledky analýz vybraných organických mikropolutantů v materiálech za rok 2018 Tab. 2. Results of analyzes of selected organic micropollutants in materials in 2018

\begin{tabular}{|c|c|c|c|}
\hline Látka & Jednotky & Vstupní kal & Směs po skončení procesu \\
\hline Atenolol & ug/kg suš & 3,3 & $<1,0$ \\
\hline Bezafibrate & ug/kg suš & $<1,0$ & $<1,0$ \\
\hline Caffein & ug/kg suš & 1220,0 & $<2,0$ \\
\hline Clarithromycin & ug/kg suš & 354,0 & 7,1 \\
\hline Diclofenac & ug/kg suš & 60,0 & $<10,0$ \\
\hline Diclofenac-4'-hydroxy & ug/kg suš & $<20,0$ & $<20,0$ \\
\hline Erythromycin & ug/kg suš & $<10,0$ & $<10,0$ \\
\hline Furosemide & ug/kg suš & 72,6 & $<10,0$ \\
\hline Gabapentin & ug/kg suš & 12,2 & 1,8 \\
\hline Gemfibrozil & ug/kg suš & $<1,0$ & $<1,0$ \\
\hline Hydrochlorothiazide & ug/kg suš & 78,6 & 8,0 \\
\hline Chloramphenicol & ug/kg suš & $<1,0$ & $<1,0$ \\
\hline Ibuprofen & ug/kg suš & 127,0 & $<10,0$ \\
\hline Ibuprofen-2-carboxy & ug/kg suš & 54,7 & $<5,0$ \\
\hline Ibuprofen-2-hydroxy & ug/kg suš & 54,1 & $<20,0$ \\
\hline lohexol & ug/kg suš & $<10,0$ & $<10,0$ \\
\hline lopamidol & ug/kg suš & $<10,0$ & $<10,0$ \\
\hline lopromide & ug/kg suš & $<10,0$ & $<10,0$ \\
\hline Karbamazepin & ug/kg suš & 49,7 & 10,7 \\
\hline Karbamazepin-2-hydroxy & ug/kg suš & 2,4 & $<1,0$ \\
\hline Karbamazepin 10,11-dihydro-10-hydroxy & ug/kg suš & $<1,0$ & $<1,0$ \\
\hline Karbamazepin 10,11-dihydroxy & ug/kg suš & $<1,0$ & $<1,0$ \\
\hline Karbamazepin 10,11-epoxid & ug/kg suš & $<1,0$ & $<1,0$ \\
\hline Ketoprofen & ug/kg suš & 2,6 & $<1,0$ \\
\hline Metoprolol & ug/kg suš & 96,5 & 6,4 \\
\hline Naproxene & ug/kg suš & 17,0 & $<10,0$ \\
\hline Naproxene-O-desmethyl & ug/kg suš & 15,1 & $<5,0$ \\
\hline Oxcarbazepine & ug/kg suš & $<1,0$ & $<1,0$ \\
\hline Paracetamol & ug/kg suš & $<2,0$ & $<2,0$ \\
\hline Peniciline G & ug/kg suš & 1,1 & $<1,0$ \\
\hline Roxithromycin & ug/kg suš & 7,8 & 2,1 \\
\hline Saccharin & ug/kg suš & 70,2 & $<10,0$ \\
\hline Sertraline & ug/kg suš & 200,0 & 25,2 \\
\hline Sulfamerazine & ug/kg suš & $<1,0$ & $<1,0$ \\
\hline Sulfamethazin & ug/kg suš & $<1,0$ & $<1,0$ \\
\hline Sulfamethoxazol & ug/kg suš & $<1,0$ & $<1,0$ \\
\hline Sulfanilamide & ug/kg suš & $<10,0$ & $<10,0$ \\
\hline Sulfapyridin & ug/kg suš & 80,7 & 3,8 \\
\hline Tramadol & ug/kg suš & 27,0 & 7,5 \\
\hline
\end{tabular}




\begin{tabular}{llcc}
\hline Látka & Jednotky & Vstupní kal & Směs po skončení procesu \\
\hline Triclocarban & ug/kg suš & 63,9 & 237,0 \\
\hline Triclosan & ug/kg suš & 236,0 & 115,0 \\
\hline Trimetoprim & ug/kg suš & 46,7 & $<10,0$ \\
\hline Venlafaxine & ug/kg suš & 279,0 & 36,2 \\
\hline Warfarin & ug/kg suš & $<1,0$ & $<1,0$ \\
\hline
\end{tabular}

Oranžové zvýraznění - látka byla detekována zvolenou analytickou metodou

Tab. 3. Výsledky analýz vybraných organických mikropolutantů v materiálech za rok 2019

Tab. 3. Results of analyzes of selected organic micropollutants in materials in 2019

\begin{tabular}{|c|c|c|c|}
\hline Látka & Jednotky & Vstupní kal & Směs po skončení procesu \\
\hline Acebutolol & ug/kg suš & 35,6 & 2,2 \\
\hline Acesulfam & ug/kg suš & 11,2 & $<2,0$ \\
\hline Atenolol & ug/kg suš & $<1,0$ & $<1,0$ \\
\hline Bezafibrate & ug/kg suš & $<1,0$ & $<1,0$ \\
\hline Bisfenol B & ug/kg suš & $<5,0$ & $<5,0$ \\
\hline Bisfenol S & ug/kg suš & 4,1 & $<1,0$ \\
\hline Bisoprolol & ug/kg suš & 2,5 & $<1,0$ \\
\hline Caffein & ug/kg suš & 9,4 & $<2,0$ \\
\hline Celiprolol & ug/kg suš & 1,0 & 2,9 \\
\hline Clarithromycin & ug/kg suš & $<10,0$ & $<10,0$ \\
\hline Clindamycin & ug/kg suš & 3,4 & $<1,0$ \\
\hline Clofibric acid & ug/kg suš & $<2,0$ & $<2,0$ \\
\hline Cyclophosphamide & ug/kg suš & $<1,0$ & $<1,0$ \\
\hline Diclofenac & ug/kg suš & $<10,0$ & $<10,0$ \\
\hline Diclofenac-4'-hydroxy & ug/kg suš & $<20,0$ & $<20,0$ \\
\hline Erythromycin & ug/kg suš & $<10,0$ & $<10,0$ \\
\hline Fluconazole & ug/kg suš & $<1,0$ & $<1,0$ \\
\hline Furosemide & ug/kg suš & $<10,0$ & $<10,0$ \\
\hline Gabapentin & ug/kg suš & 4,1 & $<1,0$ \\
\hline Gemfibrozil & ug/kg suš & $<1,0$ & $<1,0$ \\
\hline Hydrochlorothiazide & ug/kg suš & 6,6 & $<2,0$ \\
\hline Chloramphenicol & ug/kg suš & $<1,0$ & $<1,0$ \\
\hline Ibuprofen & ug/kg suš & 12,1 & $<10,0$ \\
\hline Ibuprofen-2-carboxy & ug/kg suš & 50,6 & $<5,0$ \\
\hline Ibuprofen-2-hydroxy & ug/kg suš & $<20,0$ & $<20,0$ \\
\hline lohexol & ug/kg suš & $<10,0$ & $<10,0$ \\
\hline lomeprol & ug/kg suš & $<10,0$ & $<10,0$ \\
\hline lopamidol & ug/kg suš & $<10,0$ & $<10,0$ \\
\hline lopromide & ug/kg suš & $<10,0$ & $<10,0$ \\
\hline
\end{tabular}




\begin{tabular}{|c|c|c|c|}
\hline Irbesartan & ug $/ \mathrm{kg}$ suš & 9,6 & 9,4 \\
\hline Karbamazepin & ug/kg suš & 23,8 & 4,5 \\
\hline Karbamazepin-2-hydroxy & ug/kg suš & 1,3 & $<1,0$ \\
\hline Karbamazepin 10,11-dihydro-10-hydroxy & ug/kg suš & $<1,0$ & $<1,0$ \\
\hline Karbamazepin 10,11-dihydroxy & ug/kg suš & $<1,0$ & $<1,0$ \\
\hline Karbamazepin 10,11-epoxid & ug/kg suš & $<1,0$ & $<1,0$ \\
\hline Ketoprofen & ug/kg suš & 1,1 & $<1,0$ \\
\hline Lamotrigine & ug/kg suš & $<10,0$ & $<10,0$ \\
\hline Lovastatin & ug/kg suš & $<2,0$ & $<2,0$ \\
\hline Memantine & ug/kg suš & $<2,0$ & $<2,0$ \\
\hline Metoprolol & ug/kg suš & 21,3 & 1,5 \\
\hline Naproxene & ug/kg suš & $<10,0$ & $<10,0$ \\
\hline Naproxene-O-desmethyl & ug/kg suš & $<5,0$ & $<5,0$ \\
\hline Oxcarbazepine & ug/kg suš & $<1,0$ & $<1,0$ \\
\hline Paracetamol & ug/kg suš & $<2,0$ & $<2,0$ \\
\hline Peniciline G & ug/kg suš & $<1,0$ & $<1,0$ \\
\hline Phenazone & ug/kg suš & $<2,0$ & $<2,0$ \\
\hline Primidone & ug/kg suš & $<1,0$ & $<1,0$ \\
\hline Propranolol & ug/kg suš & $<1,0$ & $<1,0$ \\
\hline Propyphenazone & ug/kg suš & $<1,0$ & $<1,0$ \\
\hline Roxithromycin & ug/kg suš & $<1,0$ & $<1,0$ \\
\hline Saccharin & ug/kg suš & $<10,0$ & $<10,0$ \\
\hline Sertraline & ug/kg suš & 63,8 & 10,5 \\
\hline Simvastatin & ug/kg suš & $<10,0$ & $<10,0$ \\
\hline Sotalol & ug/kg suš & $<1,0$ & $<1,0$ \\
\hline Sulfamerazine & ug/kg suš & $<1,0$ & $<1,0$ \\
\hline Sulfamethazin & ug/kg suš & $<1,0$ & $<1,0$ \\
\hline Sulfamethoxazol & ug/kg suš & $<1,0$ & $<1,0$ \\
\hline Sulfanilamide & ug/kg suš & $<10,0$ & $<10,0$ \\
\hline Sulfapyridin & ug/kg suš & 3,2 & 1,0 \\
\hline Tiamulin & ug/kg suš & $<1,0$ & $<1,0$ \\
\hline Tramadol & ug/kg suš & 8,4 & 1,8 \\
\hline Triclocarban & ug/kg suš & 61,9 & 189,0 \\
\hline Triclosan & ug/kg suš & 188,0 & 66,1 \\
\hline Trimetoprim & ug/kg suš & $<10,0$ & $<10,0$ \\
\hline Valsartan & ug/kg suš & $<5,0$ & $<5,0$ \\
\hline Venlafaxine & ug/kg suš & 56,8 & 9,8 \\
\hline Warfarin & ug/kg suš & $<1,0$ & $<1,0$ \\
\hline
\end{tabular}

Oranžové zvýraznění - látka byla detekována zvolenou analytickou metodou 
Peletované hnojivo typ startér („Startér S1“ v tab. 4) v sobě kombinuje vlastnosti organické hmoty (čistírenského kalu) k stabilizaci minerální formy živin ve snaze zabránit jejich rozplavení. Složení hnojiva typu startér vychází z doporučené dávky makroprvků podle publikace Hluška a Richtera [13], přičemž poměr jednotlivých prvků v novém hnojivu byl nastaven podle pravidel využitelnosti makro a mikroprvků v kompetici s dusíkem podle publikace Szabla [14]. Dávkování nového hnojiva se rídí pravidly agronormativu podle vyhlášky 377/2013 Sb. [15], vydané Ministerstvem zemědělství (MZe) v platném znění. Na základě těchto př́stupů se podařilo připravit nové, relativně stabilní hnojivo s krátkým poločasem uvolnění potřebných živin ve prospěch rostlin, které se dobře dávkuje do půdy běžnými zemědělskými stroji.

Peletované hnojivo typ fertilizér („„Fertilizér F1“ v tab. 4) v sobě kombinuje vlastnosti organické hmoty (čistírenského kalu) a vápnitého prekurzoru. Kombinace těchto dvou složek je v zemědělství již řadu let odzkoušena. Výhodným zdrojem vápnitého prekurzoru se ukázalo být využití saturačního kalu z výroby cukru (neboli tzv. šámy). Šáma obsahuje kromě sraženého $\mathrm{CaCO}_{3}$ (75 až 77 \% hmotnosti v sušině) i další vysrážené soli, hlavně MgO (až 4 \% hmotnosti), a zejména vysokomolekulární koagulované necukry (1,1 až 1,7 \% hmotnosti v sušině) [16]. Šáma je zdrojem sacharózy (až 4 \% hmotnosti v sušině), což pozitivně působí na rozvoj mikrobiální složky pưd [18]. Aplikace šámy vzhledem k vysokému podílu necukrů má výrazně pozitivní vliv na rozvoj půdního mikrobiálního společenstva, což vede nejen k posílení půdní struktury, ale i k rozvoji půdních mikroorganismů, a tím k zlepšení „zdraví půdy“.

Výhoda zvolené technologie spočívá predevším v nastavení optimálního složení a vlhkosti vstupujících materiálů k efektivní výrobě pelet o průměru $8 \mathrm{~mm}$, uzpůsobených k aplikaci do zóny růstu plodin.

Tab. 4 ukazuje výsledné prvkové složení obou připravených matric. Prvkové složení a vybrané charakteristiky, např. hodnoty pH, jsou uvedeny jako průměrné měřené hodnoty z více opakování. Dále je uvedena hodnota směrodatné odchylky datového souboru pro každý parametr a prvek. Z pohledu hnojivého účinku matrice typu startér obsahuje téměř polovinu obsahu dusíku v amonné formě $\left(\mathrm{N}-\mathrm{NH}_{4}^{+}\right)$, což je pro výživu rostlin pozitivní. Obsah amonné a nitrátové formy dusíku (5,45\%) se blíží teoretické hladině 6 \% dusíku (N). Odpovídající je i obsah prístupného fosforu (P) 2,08 \% (teoreticky 2,5\%), přístupného draslíku (K) 2,85 \% (teoreticky 3,3\%) a hořčíku (Mg) 0,66 \% (teoreticky 0,6 \%).

$\checkmark$ matrici typu fertilizér už tolik nezáleží na odpovídajícím prvkovém složení, zde jsou podstatné vlastnosti popisující kvalitu půdní organické hmoty, prèdevším obsah humusu, jenž tvoři 18 \%, dále kvalitu huminových složek Q4/6, která je vysoce nad hranicí 4 (hodnota barevného kvocientu), charakterizující kvalitní huminové složky, a zejména vysoký obsah snadno rozložitelných C složek (C-hws). Obsah prístupného vápníku (Ca) v matrici se pohybuje kolem 4 \%.

Rozsah chemického složení obou hnojiv může v rámci přípravy značně kolísat. Důvodem je:

1. variabilní prvkové složení čistírenského kalu, jak ukazuje publikace Černého [17]

2. rozsah vstupních parametrů z cukrovarnického kalu (šámy), jak ukazuje publikace Šárky [16]

Nová peletovaná hnojiva na bázi čistírenských kalů z RB technologie jsou vyráběna ve formě pelet o průměru $8 \mathrm{~mm}$. Pro prípravu pelet je nutné připravit materiál o sušině 75 až $80 \%$ hm. Právě peletovaná forma hnojiva umožní jeho snadnou skladovatelnost a aplikovatelnost pomocí zemědělské mechanizace př́mo do zóny růstu konkrétních plodin.
Tab. 4. Živinové složeni pripravených hnojiv

Tab. 4. Nutrient composition of prepared fertilizers

\begin{tabular}{|c|c|c|c|c|c|c|c|}
\hline \multirow{2}{*}{$\begin{array}{l}\text { Označení } \\
\text { analýzy }\end{array}$} & \multirow{2}{*}{ Jednotka } & \multicolumn{3}{|c|}{ Startér S1 } & \multicolumn{3}{|c|}{ Fertilizér F1 } \\
\hline & & PRUM & \pm & SM & PRUM & \pm & SM \\
\hline $\mathrm{pH} \mathrm{H}_{2} \mathrm{O}$ & & 5,30 & \pm & 0,00 & 7,21 & \pm & 0,01 \\
\hline $\mathrm{pH} \mathrm{KCl}$ & & 5,26 & \pm & 0,00 & 7,13 & \pm & 0,01 \\
\hline sorpce T (CEC) & $\mathrm{mmol}+/ 100 \mathrm{~g}$ & 32,85 & \pm & 0,34 & 46,70 & \pm & 0,33 \\
\hline $\mathrm{N} / \mathrm{NO}_{3}$ & $\mathrm{mg} / \mathrm{kg}$ & 3,05 & \pm & 0,03 & 0,12 & \pm & 0,00 \\
\hline $\mathrm{N} / \mathrm{NH}_{4}$ & $\mathrm{mg} / \mathrm{kg}$ & 2,40 & \pm & 0,01 & 0,06 & \pm & 0,01 \\
\hline Ntot & $\%$ & 3,71 & \pm & 0,23 & 1,44 & \pm & 0,02 \\
\hline Cox & $\%$ & 7,66 & \pm & 0,26 & 10,79 & \pm & 0,10 \\
\hline humus & $\%$ & 13,18 & \pm & 0,44 & 18,55 & \pm & 0,16 \\
\hline Q (472/644) & & 5,5 & \pm & 0,0 & 6,0 & \pm & 0,0 \\
\hline C-hws & $\%$ & 0,44 & \pm & 0,02 & 0,32 & \pm & 0,00 \\
\hline prístupný Ca & $\%$ & 1,84 & \pm & 0,03 & 3,67 & \pm & 0,02 \\
\hline prístupný K & $\%$ & 2,85 & \pm & 0,05 & 0,09 & \pm & 0,00 \\
\hline príistupný Mg & $\%$ & 0,66 & \pm & 0,01 & 0,16 & \pm & 0,00 \\
\hline príistupný P & $\%$ & 2,08 & \pm & 0,01 & 0,12 & \pm & 0,00 \\
\hline vázaný K & $\%$ & 0,30 & \pm & 0,00 & 0,30 & \pm & 0,03 \\
\hline vázaný Mg & $\%$ & 0,92 & \pm & 0,00 & 0,57 & \pm & 0,00 \\
\hline vázaný Ca & $\%$ & 3,39 & \pm & 0,10 & 6,69 & \pm & 0,07 \\
\hline vázaný P & $\%$ & 3,07 & \pm & 0,03 & 1,25 & \pm & 0,01 \\
\hline vázané Fe & $\%$ & 1,38 & \pm & 0,00 & 2,47 & \pm & 0,03 \\
\hline vázaný Co & $\mathrm{mg} / \mathrm{kg}$ & 40,06 & \pm & 0,01 & 6,39 & \pm & 0,03 \\
\hline vázaný Mn & $\mathrm{mg} / \mathrm{kg}$ & 197 & \pm & 0 & 288 & \pm & 2 \\
\hline vázaný Mo & $\mathrm{mg} / \mathrm{kg}$ & 26,84 & \pm & 0,27 & 3,61 & \pm & 0,02 \\
\hline vázaný Zn & $\mathrm{mg} / \mathrm{kg}$ & 798 & \pm & 18 & 966 & \pm & 36 \\
\hline
\end{tabular}

\section{ZÁVĚR}

Studie prokázala, že využití technologie založené na extenzivním odvodnění kalů a jejich stabilizaci v kalových polích s vhodnou mokřadní vegetací, prípadně s využitím ochrany proti ředění vysoušené směsi srážkami (skleník, střiška), může představovat alternativu k jiným technologiím, zejména v kombinaci s KČOV. Podmínkou je dostatečně velká plocha pozemků, což je často př́klad malých obcí, které KČOV využívají.

Procesy probíhající $v$ RB jednotkách s napuštěnými čistírenskými kaly a s vegetací mokřadních rostlin popisuje řada zahraničních publikací $[8,9]$. Hlavní provozní zásady, chyby při návrzích a provozu i doporučení pro další nakládání s odvodněnou hmotou shrnuje práce Brixe [4]. Při návrhu RB jednotek pro určité území je nutné v závislosti na klimatických podmínkách hledat 
optimální interval a délku periody napouštění a vysoušení. Extenzivní čistírny (kořenové čistírny, umělé mokřady apod.) mají nižší produkci kalu spojenou s provozem objektů mechanického předčištění (různé typy usazovacích nádrží nebo vícekomorových septikü), zpravidla s vyvážením několikrát ročně. Dosažené výsledky ukazují, že i s ohledem na co nejvyšší eliminaci organických mikropolutantů bude nutné ponechání materiálu v jednotce po ukončení napouštění a vysoušení po doporučovanou dobu jedné sezony (letní či zimní) [1, 3], což umožní mineralizaci materiálu, jeho hygienizaci a stabilizaci. Výsledná hmota by měla dosáhnout vlastností a složení srovnatelného s konečnými produkty kompostování kalů s biologickými složkami [2], jak ukazují výsledky rozboru materiálů z pokusných RB jednotek po jejich odstavení na dobu několika měsíců.

Popsaná technologie odvodnění čistírenských kalů může být prvním stupněm úpravy, který při zajištění následných vhodných kroků, např. standardizace substrátů (prídavkem dalších príměsí, zpracováním do peletek apod.) otevírá cestu pro racionální využití kalů na orné půdě. $V$ našem případě bylo upraveného a vysušeného kalu z RB jednotek využito k přípravě organominerálních hnojiv. Predpokládáme, že aplikace organominerálních hnojiv do půdy bude mít vysoce pozitivní vliv nejen pro tvorbu stabilní půdní struktury, ale především téměř eliminuje riziko spojené s vyplavováním dusíku a fosforu do povrchových a podzemních vod. Při uplatnění kompostovaného materiálu na půdu se předpokládá také významný krycí efekt, kdy kompost aplikovaný na povrch půdy působí jako mulč a významně snižuje riziko vzniku vodní eroze.

\section{Poděkování}

Príspěvek byl zpracován za finanční podpory projektu S502030008 „Centrum environmentálního výzkumu: Odpadové a oběhové hospodářství a environmentální bezpečnost" a s využitím výsledků projektu TH02030532 "Nové postupy úpravy a stabilizace čistírenských kalů z malých komunálních zdrojü"v rámci jeho implementace.

\section{Literatura}

[1] JAROLímOVÁ, V. Aplikace kalů z čistíren odpadních vod na zemědělské půdě a související legislativa. Biom.cz [on-line]. 27. červen 2019 [vid. 16. záŕi 2021]. Dostupné z: https://biom.cz/cz/ odborne-clanky/aplikace-kalu-z-cistiren-odpadnich-vod-na-zemedelske-pude-a-souvisejicilegislativa

[2] PAUL, E. A., CLARK, F. E. Soil Microbiology and Biochemistry. New York: Academic Press, (1996), $340 \mathrm{~s}$.

[3] GUO, L. B., GIFFORD, R. M. Soil Carbon Stocks and Land Use Change: A Meta Analysis. Global Change Biology. 2002, 8, s. 345-360

[4] BRIX, H. Sludge Dewatering and Mineralization in Sludge Treatment Reed Beds. Water. 2017, 9, s. 160 [5] ROZKOŠNÝ, M ŠEREŠ, M. HUDCOVÁ, H., HNÁTKOVÁ, T., MRVOVÁ, M. Sludge Dewatering Reed Beds and their Performance in Terms of Sludge Quality Improvement at Small Wastewater Treatment Plants. Waste Forum. 2020, č. 4, s. 201-216

[6] KANNEPALLI, S. et al. Composting of Aged Reed Bed Biosolids for Beneficial Reuse: A Case Study in New Jersey, USA. Compost Science and Utilization. 2016, 24(4), s. 281-290

[7] KOLECKA, K. et al. Integrated Dewatering and Stabilization System as an Environmentally Friendly Technology in Sewage Sludge Management in Poland. Ecological Engineering. 2017, 98, s. 346-353

[8] PERUZZI, E. et al. Stabilization Process in Reed Bed Systems for Sludge Treatment. Ecological Engineering. 2017, 102, s. 381-389

[9] UGGETTI, E., FERRER, I., LLORENS, E., GARCÍA, J. Sludge Treatment Wetlands. A Review on the State of the Art. Bioresource Technology. 2010, 101, s. 2905-2912

[10] Vyhláška č. 437/2016 Sb., o podminkách použiti upravených kalů na zemědělské pưdě. Pozn. Zrušena k 1. lednu 2021. Náhrada: Vyhláška č. 273/2021 Sb., o podrobnostech nakládání sodpady

[11] ROZKOŠNÝ, M., HUDCOVÁ, H., PLOTĚNÝ, M., NOVOTNÝ, R., MATYSÍKOVÁ, J. Kvalita kalů a odpadů z domovních a malých ČOV a možnosti jejich využití v zemědělství. Vodohospodářské technickoekonomické informace. 2015, 57(6), s. 44-49

[12] VINCENT, J., FORQUET, N., MOLLE, P., WISNIEWSKI, Ch. Mechanical and Hydraulic Properties of Sludge Deposit on Sludge Drying Reed Beds (SDRBs): Influence of Sludge Characteristics and Loading Rates. Bioresource Technology. 2012, 116, s. 161-169
[13] HLUŠEK, J. RICHTER, R. Bilance živin v rostlinné výrobě ČR a potřeba hnojení. Racionální použit hnojiv - sborník z konference. 2006. Biom.cz [on-line]. [vid. 16. záři 2021]. Dostupné z: https://biom.cz/ cz/odborne-clanky/bilance-zivin-v-rostlinne-vyrobe-cr-a-potreba-hnojeni. ISBN 978-80-213-2006-2.

[14] SZABLA, K. Szkółkarstwo kontenerowe: nowe technologie i technikiw szkółkarstwie leśnym. Warszawa: Centrum Informacji Lasów Państwowych, 2003. ISBN 97-8838-8478437.

[15] Vyhláška č. 377/2013 Sb., o skladování a zpưsobu používání hnojiv

[16] ŠÁRKA, E. Saturační kal - možnosti použití a vlastnosti. Listy cukrovarnické a řepařské. 2008, 40, 124(12), s. 349-357

[17] ČERNÝ,J.VyužitíodpadůzČOVjakozdrojeorganických látekaživin.2009. Biom.cz[on-line]. 8.záŕí2014 [vid.16.záŕi2021].Dostupnéz:https://biom.cz/cz/projekty/konference-racionalni-pouziti-hnojiv-2009

[18] RICHTER, R., HLUŠEK, J. Výživa a hnojení rostlin (I. obecná část). Brno: VŠZ, 1994. 177 s. ISBN $80-7157-138-5$

\section{Autoři}

Ing. Josef Kratina, Ph.D.1

凶josef.kratina@vuv.cz

ORCID: 0000-0001-6095-586X

Ing. Miloš Rozkošný, Ph.D.²

凶milos.rozkosny@vuv.cz

ORCID: 0000-0002-6617-5431

Ing. Hana Hudcová, Ph.D. ${ }^{2}$

凶hana.hudcova@vuv.cz

ORCID: 0000-0002-7462-9333

Mgr. Michal Šereš ${ }^{3}$

$\bowtie$ michal.seres@dekonta.cz

\section{Ing. Ondřej Holubík ${ }^{4}$}

凶holubik.ondrej@vumop.cz

ORCID: 0000-0002-6519-5887

'Výzkumný ústav vodohospodářský T. G. Masaryka, Praha ${ }^{2}$ Výzkumný ústav vodohospodářský T. G. Masaryka, Brno ${ }^{3}$ DEKONTA, a. s, Dřetovice

${ }^{4}$ Výzkumný ústav meliorací a ochrany půdy, Praha

Příspěvek prošel lektorským řízením.

DOI: 10.46555/VTEI.2021.09.004 
STUDY OF THE EFFECTIVENESS

OF THE SMALL MUNICIPAL SOURCES

SEWAGE SLUDGE EXTENSIVE STABILIZATION

FOR THEIR USE AS A FERTILIZER

KRATINA, J.'; ROZKOŠNÝ, M. ${ }^{2}$; HUDCOVÁ, H. ${ }^{2}$; ŠEREŠ, M. ${ }^{3}$;

HOLUBÍK, 0. ${ }^{4}$

${ }^{1}$ T. G. Masaryk Water Research Institute Prague

${ }^{2}$ TGM Water Research Institute Brno

${ }^{3}$ Dekonta, Ltd.

${ }^{4}$ Research Institute for Soil and Water Conservation Prague

Keywords: sewage sludge - sludge dewatering - sludge stabilization soil quality - organic matter - composting - fertilization substrate

The article is devoted to the presentation of partial results of a study aimed at determining the potential use of extensive sludge dewatering technology for small municipal WWTPs (up to 1000 PE) in the conditions of the Czech Republic. The study has shown that the use of technology based on extensive sludge dewatering and their stabilization in sludge dewatering reed beds with suitable wetland vegetation can be an alternative to other technologies. Especially in combination with constructed wetland (CW) based WWTPs, which are characterized by lower sludge production. A sufficiently large area of available land for such technology is a key parameter. This is often an example of small municipalities that use CW WWTPS. The described technology of dewatering of sewage sludge can open the way for rational use of sludge on arable land by ensuring the first suitable treatment and standardization of substrates (mixing with selected additives, further processing into pellets, etc.). We assume that the application of organo-mineral fertilizers to the soil will have a highly positive effect not only on the formation of a stable soil structure, but above all almost eliminates the risk associated with leaching $\mathrm{N}$ and $\mathrm{P}$ into water. 